DOI: $10.33067 /$ SE.2.2020.7

Erhan Akdemir ${ }^{\star}$

\title{
Chinese Strategy Towards Europe: The Belt and Road Initiative and $17+1$ Strategy - What Does It Mean for the EU and Central and Eastern Europe?
}

\begin{abstract}
Several projects like the Silk Road have been developed by different countries in the post-1991 period, but there is only one that had a tremendous global impact: the "One Belt One Road" (Belt and Road) Initiative developed by China. This project was first announced by the Chinese President Xi Jinping during his visit to Central Asia in 2013, and has subsequently had a tremendous global, regional and national effect. The Belt and Road Initiative not only covers almost the entire Asian continent, but also a large geographical area that extends from East Africa to Europe. Through this project China aims to promote common development and welfare sharing among all countries along the Belt and Road routes, to establish mutual political trust between China and these countries, to more effectively connect transportation networks among regions and cities along the routes, and to establish cultural contact between societies. Accordingly, China wants to put its development process on a planned and solid basis by increasing its global impact in the economic, political, and cultural fields.
\end{abstract}

Keywords: China, International Relations, European Union, $17+1$ Strategy

\section{Introduction}

Official relations between the EU and China started on May 6, 1975. After this date, a trade agreement was signed between China and the EU

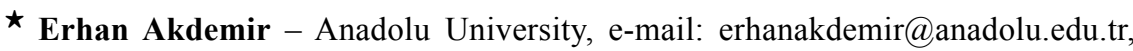
ORCID: 0000-0002-4579-3759. 
on May 2, 1978, wherein the two parties assigned the most privileged nation status to one another. ${ }^{1}$ The first scientific-technological cooperation projects between China and the EU were launched in 1983. The Agreement on Trade and Economic Cooperation between the European Economic Community and the People's Republic of China was then signed on May 21, 1985 and remains the main legal framework for EU-China relations to this day. Subsequently the EU Delegation was opened in Beijing in 1988. ${ }^{2}$ Throughout the 1980 s several commercial cooperation agreements were signed between the parties and multinational European firms invested in China, which contributed to the Chinese economy's process of transformation into an economy focused on consumption, service, and technology. From the beginning of the 1990s commercial relations between the EU and China started to revive, while their political and diplomatic relations simultaneously began to institutionalize. The first summit between the EU and China was held in 1998 and a total of 21 summits, including the April 2019 Summit, have now been held. Furthermore, a comprehensive strategic partnership between the two parties was announced in 2002.

\section{Economic Relations between the European Union (EU) and China}

Since the 2008 Eurozone Debt Crisis, China-EU economic relations, regarding both trade and direct capital investments, have drawn the attention of world public opinion together, as have their social and political outcomes. Hence, foreign investments toward the EU originating in China increased significantly after the "2008 Debt Crisis". Furthermore, in addition to trade- and direct-capital investments economic initiatives using capital of Chinese-origin through government enterprises and private companies have also become increasingly prominent in different sectors. Today, dialogue and cooperation mechanisms exist between the two parties across more than 50 sectors, including trade, environment, energy, and education; it was within this context that contact groups for the EU-China High-Level Economic and Trade Dialogue and the China-EU High-Level Strategic Dialogue were established in 2008 and 2010, respectively. The economic relations between China and the EU changed to incorporate a new dimension within the framework of free

1 J.A.G. Roberts, The Complete History of China, Sutton Publishing, Basingstoke 2003, p. 460.

2 O. Griese, EU-China relations an assessment by the communications of the European Union, “Asia Europe Journal”, no. 4/2006, pp. 545-547. 
trade when China became a member of the World Trade Organization (WHO) in 2011, which increased the China-EU bilateral trade volume. Today, one fifth of all EU imports and one tenth of all EU exports are sent to or from China. The trade volume between China and the EU was valued at around USD 615.1 billion in 2014 and USD 700 billion in 2015. In addition, $17.5 \%$ of the foreign direct investments originating from China - which reached a total of USD 200 billion in 2016 - are canalized to EU countries. ${ }^{3}$ As part of its "Go Out" (zouchuqu) policy, China has started buying Eurobonds and making huge infrastructural investments in the Euro Zone. Subsequently, Chinese state-owned enterprises and private companies have thereby gained influence in different areas in many EU countries. These investments increased by $77 \%$ between 2015 and 2016 when they reached 36.5 billion USD, comprising $4 \%$ of the EU's total foreign direct investment stock at the year of $2016 .{ }^{4}$ In this context, imports between the two parties - which amounted to 345 billion euros in 2016 - increased by $8.6 \%$ in 2017, reaching a total of 375 billion euros, with the EU running an import deficit of 176 billion euros with China. According to data from 2018, the People's Republic of China is the EU's second largest trade partner after the USA, and the EU is China's largest trading partner, with the two parties trading over 1 billion euros a day on average. ${ }^{5}$ Additionally, China has invested billions of euros in EU countries in recent years, investment that amounted to 37 billion euros in 2016, 18 billion euros in 2018, and 12 billion euros in 2019. In addition to capital investments, consumer products and services became another main target of Chinese investors in 2019. Chinese companies have also started to accelerate their research and development $(\mathrm{R} \& \mathrm{D})$ cooperation with companies, universities, and governments in the EU. ${ }^{6}$ China's foreign investments in the EU directly affect the employment of around eight million people throughout the EU, and constitute a very important part of its economy. The EU and its member states also intend to benefit

3 Trade in Goods with China, European, European Commission, http://trade. ec.europa.eu/doclib/docs/2006/september/tradoc_113366.pdf (access 10.04.2020).

4 T. Hanemann ve M. Huotari, Record Flows and Growing Imbalances: Chinese Investment in Europe in 2016, The Mercator Institute for China Studies and The Rhodium Group, January, 2017, http://rhg.com/wp-content/uploads/2017/01/RHG_Merics_COFDI_EU_2016.pdf (access 10.04.2020).

Investment, Countries and Regions, China, European Commission, https:// ec.europa.eu/trade/policy/countries-and-regions/countries/china/ (access 10.04.2020).

6 A. Kratz, M. Huotari, T. Hanemann, R. Arcesati, Chinese FDI in Europe:2019 UPDATE Special Topic: Research Collaborations, Mercator Institute for China Studies (MERICS), April 2020, p. 7, https://www.merics.org/sites/default/files/2020-04/MERICSRhodium\%20Group_COFDI-Update-2020\%20\%282\%29.pdf (access 10.04.2020). 
from China's market and economic power. These realities and intentions between China and the EU signify that China-EU relations will gain a new dimension in the future. In the light of these data, the EU wishes to take its trade relations with China one step further through the signing of a free trade agreement. However, China is not yet ready to enter into such an agreement. Today, the project that will ensure the incremental diversification, as well as the increase in and balance of trade relations between the two parties is undoubtedly the Belt and Road Initiative, an initiative devised and led by China. This is because, as is discussed in other parts of the study, this project targets and includes many economic potentials, plans, and major investments via both land and sea routes that can be shaped with China's economic leap forward toward the EU.

China's population of 1.4 billion and the EU's population of 450 million not only comprise the two largest global markets according to purchasing power, but they also comprise one third of the total gross national product globally. As no significant geopolitical conflict exists between the EU and China, who adopt the principle of multilateralism regarding international relations, ${ }^{7}$ this places international trade relations between the EU and China at the centre of EU-China bilateral relations. Accordingly, China's initiative provides it with an opportunity to increase its global trade impact and better balance its position with the EU, its biggest trade and strategic partner, while also providing the EU with the opportunity to upraise its own economic indicators.

\section{Modern Silk Road: The Belt and Road Initiative: The Spirit and Meaning of the Initiative}

To understand the Belt and Road Initiative (BRI), the 'New (Modern) Silk Road', it is first necessary to understand China's current foreign policy. Today, Chinese foreign policy is based on the reorganization of the international order, as well as the establishment of an economic, political, and cultural system outside the global economic, political, and cultural system - currently led by Western countries, especially the USA - by establishing organizations and mechanisms to substitute existing international institutions. In this respect, China opposes both the global production and management understanding of the Westernstates, especially the USA, as well as the economic, political, and cultural system envisaged by these Western states across the world. China advocates the preservation

7 China's Policy Paper on the EU: Deepen the China-EU Comprehensive Strategic Partnership for Mutual Benefit and Win-win Cooperation 2014/04/02, https://www.fmprc. gov.cn/mfa_eng/wjdt_665385/wjzcs/t1143406.shtml (access 8.04.2020). 
of the differences of civilizations based on the principle of equality within the international system. Therefore, China's opposition is not focused on the elimination of US and European states, their values, or their systems. Rather, China's opposition is therefore against the hegemonic behaviours and policies of these states. Today, China rejects the idea that it is only the USA or the European states that are positioned as the cultural, scientific, technological, and administrative leaders of the world. Due to this thesis, China is now trying to show the USA and the European states that it also represents a leading civilization and set of values. It does not accept that the values of the Western world represent the only valid value system globally and refuses the approach that the economic and political order imposed by the West is universally true and valid. Accordingly, the Belt and Road Initiative is a political, economic, and cultural project for the establishment of alternative China-based organizations and mechanisms to the existing Western-based global institutional structure. In this context, we can also consider the project to be a geopolitical, geostrategic, geoeconomic, and geocultural challenge to the status quo. Within the scope of the initiative, it is necessary to evaluate the creation of new transportation routes and trade infrastructures among Europe, Asia, and Africa according to the perspective of this transformative thesis. In this frame, China has both geopolitical and economic motivations behind the initiative. This could be also described as a more assertive China.

China's economic volume comprised $30 \%$ of global economic volume in the $1820 \mathrm{~s}$, something that attracted the attention of the colonial European states, which subsequently began to pursue colonial policies toward China. These policies, which were shaped both by internal rebellions as well as exploitation by colonial powers within China itself, marked the "Century of Humiliation" for the Chinese. This period, which started with China's defeat against Britain in the First Opium War (1839-1842) resulted in "unequal agreements" and in the handing over Hong Kong's rule to the British. The "Century of Humiliation" humiliation only ended in 1949 when the Communist Party founded the People's Republic of China and so, in this sense, China's "One Belt One Road" Initiative also forms the antithesis of the "hundred years of national humiliation".

It is necessary within this context to mention the understanding of domestic policy and economic planning in China. China's policy and economic planning is traditionally based on a medium- and long-term approach; accordingly, China's current and future policy, as well as its economic planning and development process, have a time horizon of 30 40 years. As stated by the country's President Xi Jinping, China therefore aims in the next 40 years to "build a moderately prosperous society in all 
respects" by 2021 - which marks the centenary of the Communist Party of China - and to "build a modern socialist country that is prosperous, strong, democratic, culturally advanced and harmonious" by 2049, a date that marks the centenary of the People's Republic of China itself. Within this scope, the Initiative contains both political and economic goals for China.

From this perspective, it is also necessary to evaluate China's security and energy interests, its opening of new markets and reducing transportation costs in foreign trade with Europe. According to the above, China is trying to attain four basic goals through the Belt and Road Initiative. First, China aims to accelerate the growth and development of its economy by enabling the spread of economic development globally through infrastructural investments and the opening of new trade routes. Second, China strives to secure its foreign trade by improving its relationships of interdependence with other countries/regions through global networks and partnerships. Third, through the Belt and Road Initiative, China will be given the opportunity to focus on Asia as a part of the Initiative. Fourth, China endeavours to ensure the internationalization of Chinese currency renminbi (RMB), or the yuan, by promoting its use in financial transactions. Thanks to the Initiative, China will be able to further develop its economic, political, and cultural relations with the countries along the Initiative's various trade routes. The People's Republic of China, which is set to become a global power, will have the opportunity to exercise a more powerful voice in the world arena through the Initiative.

On the other hand, China's soft power policy operates as an alternative to the hard policies pursued by other global powers concerning countries situated on the New Silk Road. ${ }^{8}$ For example, China will use the Initiative to increase its economic, commercial, and political relations and cooperation with those Central and Eastern European countries involved in the Initiative. Thanks to these relations and cooperation, China has the opportunity to apply soft power policies in Central and Eastern Europe, making China's cultural diplomacy a most important tool. In this framework, the long-term goal of Chinese cultural diplomacy is to create a good image of China among the people of Central and Eastern Europe, and then spread it to the Western and Northern Europe.

In this sense the New Silk Road project makes China a country in pursuit of a global vision. In addition, the Belt and Road Initiative

${ }^{8}$ I. Krastev, M. Leonard, New World Order: The Balance of Soft Power and the Rise of Herbivorous Powers, European Council on Foreign Relations, October 2007, http:// www.ecfr.eu/publications/summary/chinas_market_economy_status_and_the_european_ interest_7050 (access 10.04.2020). 
provides China with an opportune environment in which it can gradually increase its economic power, using its investment policies and transforming its political influence so that is more globally effective through the establishment of new relationships. Additionally, Beijing has become the centre of attraction for Eurasia due to the construction of new transportation routes and economic corridors, making the Initiative a comprehensive international initiative.

Therefore, it is necessary to consider and evaluate the One Belt One Road Initiative within the aforementioned frameworks. Chinese President $\mathrm{Xi}$ Jinping announced the Modern Silk Road Project for the first time in a speech he gave on September 7, 2013 at the Nazarbayev University in Kazakhstan. In his speech, Xi stressed China's hope to co-build the "Silk Road Economic Belt" through the development of a cooperative model with a creative spirit in order to further intensify economic connections among all Eurasian countries, deepening mutual cooperation and broadening the horizon for development. $\mathrm{Xi}$ Jinping then referred to the project as "One Belt One Road" Initiative," whereby the Initiative got its name by combining and abbreviating the names of the historical "Silk Road Economic Belt" and the modern "Sea Silk Road". The Chinese government then set up the Leading Group for Promoting the Belt and Road Initiative, with an administrative office under the National Development and Reform Commission. In March 2015, the Chinese government published Vision and Actions on Jointly Building Silk Road Economic Belt and 21st Century Maritime Silk Road. Subsequently, in May 2017, the first Belt and Road Forum for International Cooperation was convened in Beijing..$^{10}$ On May 14, 2017, the opening ceremony of the "Belt and Road Forum" was held at the China National Convention Center in Beijing Olympic Park; the ceremony was attended by 29 heads of state and government, as well as over 1,500 delegates from 130 countries and 70 international organizations. ${ }^{11}$

The Initiative aims to establish a trade and infrastructure network by connecting Europe and Africa to Asia and includes two main trade routes: The New Silk Road Economic Belt, and the $21^{\text {st }}$ Century Maritime

9 President Xi Jinping Delivers Important Speech and Proposes to Build a Silk Road Economic Belt with Central Asian Countries, 2013.09.07, https://www.fmprc.gov.cn/mfa eng/topics_665678/xjpfwzysiesgjtfhshzzfh_665686/t1076334.shtml (access 8.04.2020).

${ }_{10}$ The Belt and Road Initiative Progress, Contributions and Prospects, http://www. china-un.ch/eng/zywjyjh/t1675564.htm (access 9.04.2020).

${ }^{11}$ Full text of President Xi's speech at opening of Belt and Road forum, http://www. xinhuanet.com//english/2017-05/14/c_136282982.htm (access 9.04.2020). 
Silk Road. The New Maritime Silk Road itself comprises two routes: one which passes through the South China Sea, the Strait of Malacca, and the Indian Ocean, reaching Europe through Southeast Asia, South Asia, West Asia, and North Africa (via the Red Sea and the Mediterranean Sea); ${ }^{12}$ and a second route, which crosses the Yellow Sea, the East China Sea, and the Sea of Japan reaching the Korean Peninsula and the Far East regions of Japan and Russia. These routes serve as a channel for deepening economic and commercial cooperation as well as enriching and developing cultural ties between China and those countries along the route. As well as being transportation corridors, these routes furthermore envisage the economic integration of those countries on the New Silk Road into China. Within this framework, the Initiative includes five basic construction areas. The first is based on integrating transportation systems. For this purpose, and the project has been planned for the development and integration of railways, highways, airlines, and ports. Thus, the project is expected to reduce China's current dependence on seaways. ${ }^{13}$ The second aims to increase the infrastructural capacities of cities with the development and integration of internal markets. The third basic construction area targets the common operation and use of energy and natural resources; the project can be used to diversity those energy resources that are needed by China but that are currently owned by countries in Central Asia and the Middle East, increasing interdependence among these countries and raising their voices for the management of energy resources. Additionally, China, which has an excess capacity in many sectors, from steel to cement, will also have the opportunity to market its surpluses more easily thanks to the increased connectivity offered by the Initiative. The fourth concerns the establishment and the operation of organized industrial zones and agricultural-production farms. Another important purpose of the New Maritime Silk Road is to set up development projects that are in line with the needs of those countries along the route. ${ }^{14}$ Therefore, China's $2{ }^{\text {st }}$ Century Maritime Silk Road project is based on a broad, comprehensive, and transboundary cooperation across several fields, from "infrastructure-oriented collaborations to developmentand production-oriented collaborations.

12 R. Zhang, S. Yu, The Challenge to Maritime Silk Road and Port Connectivity, in: The 21st Century Maritime Silk Road Challenges and Opportunities for Asia and Europe, eds. K. Zou, S. Wu, Q. Ye, Routledge, London 2019, p. 15.

13 E. Oziewicz, J. Bednarz, Challenges and opportunities of the Maritime Silk Road initiative for EU countries, "Scientific Journals of the Maritime University of Szczecin", no. 59(131)/2019, pp. 110-119.

14 J. Holslag, How China's New Silk Road Threatens European Trade, "The International Spectator", vol. 52, no. 1/2017, pp. 48-51. 
On the other hand, the historical Silk Road only offered intercontinental transportation via land. However, the One Belt One Road Initiative enables trade through land, sea, and air transportation routes. Accordingly, many countries involved in the Initiative have signed agreements in the transportation, cargo, infrastructure, energy, communication, customs, software, economy and commerce, industrial production, e-commerce, and maritime fields. Within this framework, the concept of 'belt' was used to express the nature of the roads, railways, oil and gas pipelines, and other infrastructure investments involved by the Initiative. The Initiative means the creation of a transportation network that extends from China to Venice through Central Asia and Moscow. Rather than incorporating a single route, the Initiative plans several corridors of transportation from Asia to Europe:

- China-Mongolia-Russia

- New Eurasia Land Bridge

- China-Bangladesh-India-Myanmar

- China-Central and West Asia

- China-Indochinese Peninsula

- China-Pakistan.

The concept of 'road' is used to refer the Initiative's maritime transport network: a planned transportation network that comprises the Initiative's maritime line, and that will extend from South and Southeast Asia to East Africa and the north of the Mediterranean Sea. The emphasis of this seaway route is on the South China Sea, the Indian Ocean, and the gulfs of the Middle East.

The Belt and Road Initiative extends across the continents of Asia, Europe and Africa, connecting the vibrant East Asian economic environment to the advanced European economy, while also providing countries on the route with enormous potential regarding their economic development.

As stated above, the Initiative plans to integrate into the global economy those countries that are situated along its route, and to provide capital flow to these countries, thereby increasing their employment opportunities. A total of 65 countries are involved in the Initiative, organized according to region:

East Asia: China, Mongolia.

Southeast Asia: Brunei, Cambodia, Indonesia, Laos, Malaysia, Myanmar, Philippines, Singapore, Thailand, Timor-Leste, Vietnam.

Central Asia:Kazakhstan, Kyrgyzstan, Tajikistan, Turkmenistan, Uzbekistan.

Middle East and North Africa: Bahrain, Egypt, Iran, Iraq, Israel, Jordan, Kuwait, Lebanon, Oman, Qatar, Saudi Arabia, Palestine, Syria, United Arab Emirates, Yemen. 
South Asia: Afghanistan, Bangladesh, Bhutan, India, Maldives, Nepal, Pakistan, Sri Lanka.

Europe: Albania, Armenia, Azerbaijan, Belarus, Bosnia and Herzegovina, Croatia, Czechia, Estonia, Georgia, Hungary, Latvia, Lithuania, Macedonia, Moldova, Montenegro, Poland, Russia, Serbia, Slovakia, Slovenia, Turkey, Ukraine.

\section{Economic and Geopolitical Effects of the Belt and Road Initiative}

The main sources of funding for the One Belt One Road Initiative are the Chinese development banks, the USD 40 billion Silk Road Fund, and large state-owned commercial banks. China Exim Bank also supports 1,000 projects in 49 economies worth USD 80 billion. ${ }^{15}$ Through the use of these funding resources, it is estimated that the Belt and Road Initiative investment projects, which aim to establish a transportation, industry, and trade network between China, Asia, Africa, and Europe, will add over USD 1 trillion of outward funding for foreign infrastructure over a 10-year period, starting in 2017. ${ }^{16}$ It should be highlighted at this point that most of those countries included in the Modern Silk Road Project are less developed or developing countries. Therefore, Chinese President Xi Jinping's announcement that public firms and financial institutions will be given incentives to launch and run infrastructure and construction projects outside China increases the appetite of both undeveloped or developing countries regarding the Initiative, therefore promoting China's role in the global economic system. According to this aim, China has signed agreements worth USD 30 billion with Kazakhstan, USD 15 billion with Uzbekistan, and USD 3 billion with Kyrgyzstan to help these countries develop their infrastructure and meet financial expenses relating to the Belt and Road projects. ${ }^{17}$ China also provided USD 1.4 billion of funding to the Port City Colombo in Sri Lanka. ${ }^{18}$

${ }^{15}$ China's Belt and Road Initiative in the Global Trade, Investment and Finance Landscape, "OECO Business and Finance Outlook 2018”, p. 20, https://www.oecd.org/finance/ Chinas-Belt-and-Road-Initiative-in-the-global-trade-investment-and-finance-landscape. pdf (access 9.04.2020).

${ }^{16}$ China's new silk route The long and winding road, "PwC's Growth Markets Centre", February 2016, p. 4, https:/www.pwc.com/gx/en/growth-markets-center/assets/pdf/ china-new-silk-route.pdf (access 9.04.2020).

17 R. Pantucci, S. Lain, III. The Plan: Infrastructure and Integration, "Whitehall Papers", no. 88.1/2016, p. 30 .

18 Sri Lanka's 'new Dubai': will Chinese-built city suck the life out of Colombo?, 2 August 2018, https://www.theguardian.com/cities/2018/aug/02/sri-lanka-new-dubaichinese-city-colombo (access 7.04.2020). 
The Initiative has seen USD 200 billion investment agreements having been signed unto the present date; of these, the largest project so far is the USD 68 billion China-Pakistan Economic Corridor, which connects China to Pakistan's Gwadar Port. ${ }^{19}$ These investments have enabled the Initiative to become more concrete, increasing its recognition not only in less developed or developing countries among the leading countries of Europe and Asia.

The Asian Infrastructure and Investment Bank (AIIB), which was launched within the scope of the Initiative, officially started its operations in 2016. The Bank has 54 founding members, including the BRICS (Brazil, Russia, India, China, South Africa) countries, four G7 countries (the UK, France, Italy, Germany), and several other countries, such as Egypt, Australia, and New Zealand. Today the number of members of the AIIB is $78 .^{20}$ Thus, China has largely eliminated shortages of those resources that can be used to continuously increase its investments in those countries that lie on the routes of the Initiative. According to data compiled by the AIIB, since its establishment, the Bank has funded a total of USD 13.45 billion of investment. ${ }^{21}$

As a result, it is necessary that the Belt and Road Initiative is evaluated within this framework, specifically, Beijing's desire to assume the position of a global actor within a changing and developing international system. The EU, which is increasingly involved in the discussion about being a global actor or a regional economic unity, must improve its relations with China for protection, and also to ensure its current and future economic and political power. As stated above, the EU strongly discourages its members from holding bilateral institutional relations with China. This is because its members might lose power to China if they act alone. Therefore, while Brussels is sceptical of Beijing, it has nevertheless taken steps to improve its relations with China, provided that its members act as a union. The EU-China summits, which have already held over 20 times, increased mutual convergence. At this point it should be taken into account that the attitudes and policies of Donald Trump, President of the USA, also affect the EU's approach to China.

19 China's Massive Belt and Road Initiative, January 28, 2020, https://www.cfr.org/ backgrounder/chinas-massive-belt-and-road-initiative (access 7.04.2020).

${ }^{20} \mathrm{https} / / / \mathrm{www}$.aiib.org/en/projects/list/index.html?status=Approved (access 7.04.2020).

${ }^{21}$ https://www.aiib.org/en/index.html (access 7.04.2020). 


\section{Concerns of the European Union Countries about the Initiative}

Western states, especially the USA, are concerned that China is trying to increase its global influence by allocating billions of Yuan investment projects, and thereby causing high borrowing costs in developing countries. In this way, the United States shares the concern of some in Asia that the BRI could be a Trojan horse for China-led regional development and military expansion. ${ }^{22}$ The USA has also accused China of using the BRI to drag developing countries into a debt trap offering these countries cheap loans in order to force them to sell their important assets. For example, Sri Lanka, which could not make certain loan repayments in 2017, sold a port to China, which had financed the port's construction..$^{23}$

China's New Silk Road project has also caused controversy within the EU. While on the one hand EU countries praise the vision of the Chinese government concerning the Belt and Road Initiative, they also demand that China opens its markets to increase bilateral trade on the other. As discussed in the previous chapters of the study, this EU demand overlaps with China's goals of developing its own domestic markets and increasing its urban infrastructure capacity by integrating its cities with the outside world.

EU members who are included in China's Initiative are Italy, Greece, Czechia, Poland, and Hungary, while those who are excluded, such as Germany, France and Spain, prefer to work with China in the capacity of the EU. In this respect, the countries that do not participate in the Initiative criticize the countries that have made agreements with China. Another concern of these countries is that China's policies are pursued with the aim of making EU countries more economically dependent on China through various means. It should be noted, however, that the states advocating this view allow Chinese capital to be used to take over European firms, especially German firms, thereby increasing their effectiveness on the European stage, ${ }^{24}$ as Germany is the leading country to receive the most investment in the company merger and acquisition field. A total

${ }^{22}$ A. Chatzky, J. McBride, China's Massive Belt and Road Initiative, Council on Foreign Relations https://www.cfr.org/backgrounder/chinas-massive-belt-and-road-initiative (access 15.05.2020).

${ }^{23}$ D. Brautigam, A critical look at Chinese 'debt-trap diplomacy': the rise of a meme, "Area Development and Policy", vol. 5, no 1/2020, pp. 1-14.

${ }^{24}$ Chinesische Unternehmenskäufe in Europa: Eine Analyse von M\&A-Deals 20062016, January 2017, p. 10, https://jb-partners.de/wp-content/uploads/2017/10/EY-machinesische-investoren-januar-2017.pdf (access 12.04.2020). 
of value of 22.7 billion euros was invested in German companies - in addition to 14.4 billion euros in France and 4.6 billion euros in Spain - in 2000-2019..$^{25}$ Despite this several infrastructure investment projects have been carried out in many EU countries through Chinese direct investments, operations, and lending facilities within the scope of the Initiative. Numerous highways, ports, and airports are built, operated or purchased by Chinese companies along the routes of the Initiative. However, takeovers of modern companies and the high investment presence of China on the European continent to some extent, "woke up" the EU institutions and the authorities of individual Member States. ${ }^{26}$

This "awakening" is closely related to the possible effects of Chinese capital on the EU's employment market. The EU anticipates that a total of EU citizens between 64,000 and 211,000 can lose their jobs if cheap goods originating from China have easier access to the EU market. ${ }^{27}$ This estimate increases to between 1.7 and 3.5 million job losses when indirect job losses are taken into account. ${ }^{28}$ Reports published by European think tanks on the subject state that Chinese companies are able to make huge investments in the EU due to their state support, but that this can never be true for EU-based competitor firms. Consequently, they emphasize that this clearly contradicts the principle of reciprocity. If the concentration of Chinese companies operating in the EU increases, fair trade conditions will disappear completely because Chinese companies have very low operating and production costs compared with those of European companies. Furthermore, the intellectual property rights of EU companies involved in the EU-China bilateral trade relationship present another issue of concern for the EU; this is because European companies coming to China are forced to grant ownership or usage rights of their technology to domestic Chinese entities. Consequently, measures to protect the EU market against the increasingly concentrated Chinese capital in the EU, as well as the conditions under which these measures are implemented, are increasingly debated by the EU. This raises the question of whether

${ }_{25}$ A. Kratz, M. Huotari, T. Hanemann, R. Arcesati, op. cit., p. 11.

26 B.J. Góralczyk, Poland on the Route of the Chinese Silk Road: A Chance for Development or Just a Challenge?, "Monographies", Faculty of Management University of Warsaw, 2018, http://www.wz.uw.edu.pl/portaleFiles/6133-wydawnictwo-/new structrural_2018/Bogdan_J._Goralczyk.pdf (access 14.05.2020)

27 Change in the methodology for anti-dumping investigations concerning China, "European Commission", 2016 February, p. 5, https://trade.ec.europa.eu/doclib/docs/2016/ february/tradoc_154241.pdf(access 12.04.2020).

${ }_{28}$ R.E. Scott, X. Jiang, Unilateral grant of market economy status to China would put millions of EU jobs at risk, "Economic Policy Institute", September, 2015, https://www. epi.org/publication/eu-jobs-at-risk/ (access 12.04.2020). 


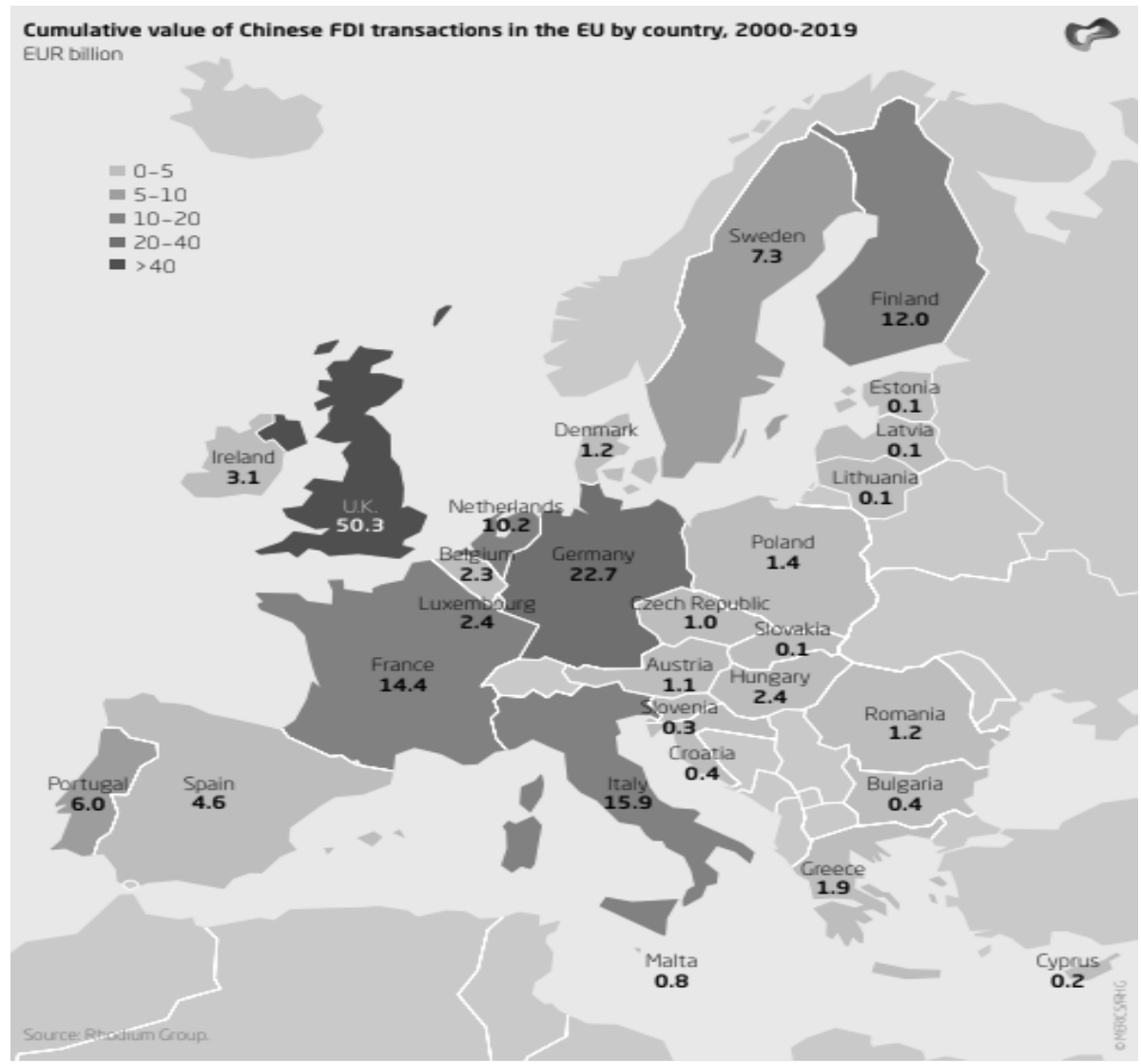

Map no. 1 Cumulative value of Chinese FDI transactions in the EU by country, 2009-2019

Source: https://www.merics.org/sites/default/files/2020-04/MERICS-Rhodium\%20 Group_COFDI-Update-2020\%20\%282\%29.pdf.

the Belt and Road Initiative is a window of opportunity for the EU, or whether the Initiative really carries the threat of a "siege".

\section{Chinese Strategy Towards Europe}

China is trying to become a global leader in international politics by using its economic power. It is therefore of great importance to the development of its commercial and economic relations with the EU, while also trying to exclude conflicting EU viewpoints from these bilateral relations. It should be emphasized here that China is sending messages to 
the USA by developing its economic and commercial relations with the EU. Considering that the USA is animportant geopolitical actor of Asia, its most important message to the US is that China is now an important actor in Europe, suggesting that there can be no Europe without China.

For China, the EU's importance extends beyond that of a commercial and economic partner; the position of the EU can also be used as a tool or a bridge to improve China's relations with the West. As a result, China has created the perception of the USA as being an "other" or an "enemy", something that is not true regarding the EU and its member states. The Chinese government, which is aware of this situation, plans to continue its mutually beneficial commercial and economic relations with the EU, and to further increase its own political and economic confidence by progressing its general foreign policy and trading process through the Belt and Road Initiative. In fact, it is essential forChina to maintain its positive relations with Europe in order to achieve its 2049 goals. Western capital has an indispensable importance for China if it is realizes its goals, and therefore China is seeking to make Western capital more dependent on its own economy.

On the other hand, as mentioned earlier in the study, due to the actions of Western powers which resulted in the "century-long humiliation something that is still fresh in the memory of many Chinese - it should also be taken into account that China may have turned this mentality into a policy of vengeance. Moreover, today China is patiently expecting to become an important global power in the world by coexisting alongside the same current global economic, political, and cultural system imposed by Western capitalist countries. China intends to do this without isolating itself from such a system, even trying to integrate into this system from time to time; in other words, China wants to stick to the 'rules of the game'. Accordingly, its relations with the EU have a vital role and importance. The "Goodwill Agreement" signed within the scope of the Belt and Road Initiative between China and EU-member Italy, in March 2019, serves as an important example of the aforementioned process. In fact, by this agreement, Italy became the first G-7 country to support the New Silk Road project, which itself carries an important message sent by China to Western countries. On the other hand, Western sources claim that China is seeking to infiltrate Western Europe by using Italy in this regard, a country that has been living in its 3rd stationary period for the past decade, something that suggests that China's message was indeed delivered to the West as intended. A second message that China may wish to send in this regard is that, rather than causing all EU countries to unite against it, instead those with whom it has good bilateral relations will 
be economically rewarded, and that those who oppose China's economic interests and huge domestic market will be deprived accordingly. In fact, it is easy to predict how other EU member states will respond to this message. In this respect, we can say that, currently at least, China has started to apply the principle of "divide and rule" - an important political approach of the West - in the EU, a heart of the West. China is not solely interested in Italy within the framework of the Belt and Road Initiative; Central and Eastern European countries (CEECs) are the main EU countries geographical regions to which China has attached great importance and focus in recent years. On the other hand, according to Zuoku the CEE region, as a region of great geographical importance in Europe and one of the most concentrated regions in terms of transportation routes in the Eurasian continent, has played a crucial role in the connectivity between China and Europe. CEECs need to carry out cooperation with China by using their geographical advantages to realize economic catching-up. ${ }^{29}$

\section{The " $17+1$ " Cooperation Platform under the Belt and Road Initiative}

CEECs refers to a group of countries in Central Europe, Southeast Europe, Northern Europe, and Eastern Europe including former European states of the 'Soviet Block'. After the collapse of the Iron Curtain in 1989-90, this term was used to refer to a total of 16 states within this geographical region: Estonia, Latvia, Lithuania, Germany (Eastern Germany), Czechia, Slovakia, Hungary, Poland, Romania, Bulgaria, Slovenia, Croatia, Albania, Bosnia and Herzegovina, Kosovo, Macedonia, Montenegro, and Serbia. This $16+1$ cooperation between these 16 CEECs and China started as a Chinese government initiative aimed at promoting business and investment relations between the 16 countries specifically within the framework of the Chinese Belt and Road Initiative. ${ }^{30}$

Subsequently, with the official participation of Greece in the ChinaCEEC cooperation in April 2019, the name of the cooperation model was changed from " $16+1$ " to " $17+1$ " to reflect Greece's inclusion. The inclusion of Greece in this cooperation was very important for China because Greece's participation will extend the 21st Century Maritime Silk Road to European-Asian trade. Greece's participation as a Western

${ }^{29}$ L. Zuokui, Europe and the "Belt and Road" Initiative: Responses and Risks, Cooperation and Development Institute, http:/cdinstitute.eu/web/wp-content/uploads/2017/08/ Liu\%20Zuokui\%20-\%20Europe\%20and\%20the\%20Belt\%20and\%20Road\%20Initiative. pdf (access 14.05.2020).

${ }^{30} \mathrm{https}: / /$ www.ceec-china-croatia.org/en/about-cooperation/ (access 12.04.2020). 
European country and a China-CEEC observer since 2016, will be the key by which Chinese-led initiatives will be able to demonstrate the Initiative's compatibility with Western systems, thereby leading to a more integrated Eurasian economy. Hungary was the first European country to sign a memorandum of understanding with China on the promotion of the Silk Road Economic Belt and the 21st-Century Maritime Silk Road.

Chinaconsiders theCEECs to comprise thecrossroads of communication and cooperation between Asia and Europe within the framework of the Belt and Road Initiative. China also considers these countries as important markets with growth potential, and so it plans to develop and deepen its cooperation with CEECs through the Belt and Road Initiative while also making CEECs an important part of China-Europe relations. Considering China's approach to make EU members more dependent on China, the value of Europe and European countries regarding the realization of China's general national strategy on the global stage becomes clear. China therefore intends to develop economic and trade-based cooperation with the 16 CEECs within this context. Furthermore, Beijing not only perceives the CEE region as one of several new frontiers for export expansion, but also as a strategic entry point into the wider European market. China chose this region because CEE countries have more dynamic, largely developed, less-saturated economies that are directly connected to the EU's common market. ${ }^{31}$ The underlying reason behind this intention is in parallel with those discussed for Western European countries in previous sections. For instance, Chinese investment in these countrieswould further strengthen the cooperation between China and CEECs, turning the whole region into Chinese hub for trade with Europe. China's approach towards cooperating with CEECs also serves the interest of the CEEs themselves. Institutional relations and collaborations between China and CEECs take place on the "17 + 1" Platform..$^{32}$ On April 25, 2012, the second China-CEECs Economic \& Trade Forum took place in Warsaw, Poland. One day layer, the leaders of China and the CEECs had their first meeting in Warsaw in the frame of the China-CEEC partnership. ${ }^{33}$

The parties, who meet annually for China-CEEC summits at the 'heads of government' level, ${ }^{34}$ have decided to remain in close and constant co-

31 Á. Szunomár, One Belt, One Road: Connecting China with Central and Eastern Europe?, in: The Belt and Road Initiative in The Global Arena: Chinese and European Perspectives, eds. Y. Cheng, L. Song, L. Huang, Singapore, 2018, p. 78.

$32 \mathrm{http} / / / \mathrm{www} . c h i n a-c e e c . o r g / \mathrm{eng} /$ (access 12.04.2020).

${ }^{33} \mathrm{http} / / /$ www.china-ceec.org/eng/msc_1/dsj/t1410557.htm (access 11.04.2020).

34 The $16+1$ countries meet annually at the Heads of Government level. So far eight summits were held: 2012 - Warsaw, Poland, 2013 - Bucharest, Romania, 2014 - Belgrade, 
operation concerning mutual political trust, economic and commercial collaboration, and cultural contacts. Another important mutual decision that was made during the first summit was when the members decided to intensify their high-level visits. Considering the relationships developed after the summit, the " $16+1$ " cooperation platform brought tangible benefits to both China and the 16 CEECs, whereby all parties received technology and financial support from one another. The completion of a thermal power plant in Bosnia Herzegovina and the progress of a railway project ${ }^{35}$ in Hungary-Serbia, which were facilitated by the investments of Chinese companies, are both important examples of that and should be mentioned at this point. This railway line, which extends across for 166 $\mathrm{km}$ in Hungary and $184 \mathrm{~km}$ in Serbia, extends from the Baltic Sea in the north to the port of Piraeus in Greece in the south. This Hungary-Serbia railway line is expected to meet the increasing logistics and transportation demands within the region. Accordingly, the railway project has potential to improve the economic development environment of CEE by directly increasing employment and investments in the region. A total of eight China-CEEC summits have been held thus far, with the 8th summit being held on 12 April 2019 in Dubrovnik, Croatia. Two important decisions were made at the 8 th summit with the aim of strengthening China-CEEC planning and coordination, and to support China in hosting the 9th China-CEEC summit, which is scheduled for $2020 .{ }^{36}$ Another institutional structuring of the $17+1$ cooperation is the China-Central and Eastern European Countries Economic and Trade Forum. The China-CEEC Inter-Bank Association was established at the end of 2017 at the initiative of the China Development Bank (CDB). There are 14 development and commercial banks in the China-CEEC Interbank Association, including the BDB, China Development Bank, and banks from Czechia, Croatia, Slovenia, Montenegro, Latvia, Lithuania, Macedonia, Hungary, Romania and Serbia. ${ }^{37}$ The purpose of the Association is to establish effective cooperation between the People's Republic of China and those CEECs aiming

Serbia, 2015 - Suzhou, China, 2016 - Riga, Latvia, 2017 - Budapest, Hungary, 2018 Sofia, Bulgaria, 2019 - Dubrovnik, Croatia.

${ }^{35}$ The train journey from Belgrade to Budapest currently takes about 8 hours, which will be reduced to 3 hours after the reconstruction of the railway line between these two cities.

${ }^{36}$ The Dubrovnik Guidelines for Cooperation between China and Central and Eastern European Countries, "Ministry of Foreign Affairs of the People's Republic of China", 2019.04.17, https://www.fmprc.gov.cn/mfa_eng/wjdt_665385/2649_665393/t1655224. shtml (access 12.04.2020).

$37 \mathrm{https}: / / \mathrm{bbr} . \mathrm{bg} / \mathrm{en} / \mathrm{n} / \mathrm{bdb}$-is-actively-involved-in-the-summit-of-heads-of-government-of-china-and-cee (access 12.04.2020). 
to strengthen economic and financial interaction among the Association's members, as well as to foster economic development, export, and investment. ${ }^{38}$ At this point, small and medium-sized enterprises constitute the Association's cooperation. China plans to increase the visibility of the New Silk Road by intensifying its cooperation with small and medium-sized enterprises in Central and Eastern Europe. The 8th Economic China-CEEC Economic and Trade Forum of was held in Sofia, Bulgaria, in July 2018. At the Forum, Chinese Prime Minister Li invited various financial institutions from CEECs to set up branch offices in China for business, and called for upgrading local cooperation between the regional cities in CEECs and China and for stepping up cultural and people-to-people exchanges between the two sides. The Chinese Prime Minister also stressed that the $16+1$ cooperation should always follow common international rules, including World Trade Organization regulations, and relevant EU legal and regulatory frameworks. Pointing out that $\mathrm{China}$ attaches great importance to its cooperation with CEECs, Chinese Prime Minister Li then went on to explain trade volume between China and the 16 CEECs grew to almost USD 70 billion from USD 40 billion, increasing an average of $6.5 \%$ annually during the 2012-2018 period. Prime Minister Li also pointed out that the share of China's trade with these countries in relation to its trade with Europe as a whole increased from $9.3 \%$ to $11 \%$, and that China's imports from these countries increased by $25 \%$ in the same period. ${ }^{39}$

The first China-CEECs Expo and International Consumer Goods Fair was held in June $2019 . .^{40}$ According to China, this platform will focus on economic and trade cooperation followinga theme that aims to "Deepen Opening up and Cooperation for a Win-win Situation", and to strive to build a platform for comprehensive exchange and cooperation among China and CEECs. Consequently, these meetings and cooperation mechanisms - held at various levels - promote cooperation between the parties at a practical level, deepening the commercial cooperation between China and CEECs and introducing many products of regional countries into the daily lives of Chinese people. Within this context, China is therefore able to bring quality products from CEECs and offer them to consumers in China at low prices. Agriculture and dairy products can be given as examples here.

Additionally, Chinese companies invest in many fields in CEEC including those of machinery, chemical industry, telecommunications, white goods, renewable energy, logistics, winter sports, research and development,

$38 \mathrm{https}$ //ceec-china-sme.org/hbor-hosts-the-meeting-of-the-china-ceec-interbank-association/ (access 12.04.2020).

${ }^{39} \mathrm{http}: / /$ www.xinhuanet.com/english/2018-07/08/c_137309738.htm (access 12.04.2020).

$40 \mathrm{https}: / /$ www.cceecexpo.org/site_en/ (access 12.04.2020). 
finance and agriculture, and the service sector. To maintain this momentum, the China-CEE Fund stepped up its commitment from USD 425 million in 2013 to USD 1 billion in 2017. According to current data, Chinese direct foreign investments in the 17 CEECs increased in the 2013-2018 period, and its foreign direct investment stock in these same countries reached a total of USD 2.5 billion in $2018 .{ }^{41}$ China plans to establish a China-Europe logistics chain and a business cooperation zone so that these data will be available in the long-term future. Chinese cities are effectively linked to the cities and ports of Western Europe countries and those of CEECs through rail and road networks and high-speed train projects.

Furthermore, it is important to note that the distribution of investments within the $16+1$ grouping is uneven; according to the data, just six CEEC countries - Bulgaria, the Czechia, Hungary, Poland, Slovakia, and Romania - account for $95 \%$ of all $16+1$ investment. $^{42}$

On the other hand, another area that has been influenced by the Initiative is that of cultural communication between China and CEECs. China promotes cultural diplomacy in order to convince the international public that the idea of One Belt One Road Initiative carries the same spirit as that of the ancient Silk Road; a spirit that is based on mutual trust, equality, mutual benefit, comprehensiveness, mutual learning, and mutually beneficial cooperation. It also promotes such diplomacy to gain the trust of Western European states by trying to create a "good image" for China. Such an effective cultural diplomacy toward CEE countries may serve as the breaking point regarding China's cultural diplomacy to be carried out across Europe in general, but especially in Western European countries. ${ }^{43}$ In this regard, it is extremely important for China to implement its cultural diplomacy strategy effectively and correctly in Central and Eastern European countries. In this respect, China considers Central and Eastern European countries as a "bridge" between the parties to demonstrate and prove through cultural diplomacy that China is not a threat to the EU. China has initiated a series of cultural diplomatic activities for Central

${ }^{41}$ Central and Eastern Europe: From $16+1$ to $17+1$, https://hkmb.hktdc.com/ en/1X0AJYOI/hktdc-research/Central-and-Eastern-Europe-From-161-to-171 (access 14.04.2020).

42 A. Kizeková, China's Belt and Road Initiative and the 16+1 Platform: The Case of the Czech Republic, in: Securing the Belt and Road Initiative Risk Assessment, Private Security and Special Insurances Along the New Wave of Chinese Outbound Investments, eds. A. Arduino, X. Gong, Singapore 2018, p. 283.

${ }^{43}$ L. Song, Z. Qiqi, A Model for the Belt and Road Initiative: China's Cultural Diplomacy Toward Central and Eastern European Countries, in: The Belt and Road Initiative in The Global Arena: Chinese and European Perspectives, eds. Y. Cheng, L. Song, L. Huang, Singapore 2018, p. 56. 
and Eastern European countries to achieve these goals. Media, trade, cultural exhibitions, education and exchange programs, and town twinning are among the cultural diplomacy activities to improve the Chinese national image in Central and Eastern European countries. Communication channels such as press, broadcasting, radio, television, film and internet are widely used by China to improve the Chinese national image in Central and Central European countries and change the negative perceptions about the country. For example, China Radio International (CRI) broadcasts in seven languages, including Czech, Serbian, Romanian, Albanian, Bulgarian, Hungarian and Polish. At the same time, CRI's online website publishes various political, economic and cultural aspects of China in Central and Eastern European country languages. ${ }^{44}$ China Council for the Promotion of International Trade (CCPIT) leads China's cultural diplomacy in trade by organizing local exhibitions and fairs in various CEEC cities in order to introduce China to local people. China's cultural diplomacy activities also include Chinese cultural festivals, including the Chinese Culture Festival Concert, Exhibition of Contemporary Art and Ink Painting, and China Film Week, in Poland, Bulgaria, and other CEECs. The Chinese government has also opened Confucius Institutes and Courses in 16 CEECs and provides scholarships to 1,000 students from these countries to learn Chinese in China. The Chinese government also provides scholarships to 5,000 students from these countries who want to study in China. Furthermore, there are more than 100 "sister cities" agreements between China and all the CEEC countries, excepting Montenegro and Estonia. The number of traditional Chinese medical treatment centres has also increased in several CEECs. As a result, the Belt and Road Initiative provides China with an opportunity to conduct cultural diplomacy activities in Central and Eastern Europe.

On the other hand, according to some opinions, so far, the response of the CEE countries to the Chinese strategy and initiatives has been lukewarm. Different business cultures and mentalities, and constraints on China from EU rules and regulations, intellectual property rights and human rights are among the main reasons for this lukewarm feeling. Another important point here is that, according to some opinions, the countries of the CEE region have never come together to form a single political community. What they need to do is to find common ground for a joint approach to China. ${ }^{45}$

${ }^{44} \mathrm{http}: / /$ chinaplus.cri.cn/ (access 14.04.2020).

45 B.J. Góralczyk, China's interests in Central and Eastern Europe: enter the dragon, "European View", Wilfried Martens Centre for European Studies, 2017, https://www. ce.uw.edu.pl/wp-content/uploads/2017/05/ev-china.pdf (access 14.05.2020). 


\section{Conclusions}

China, which has the second largest economy in the world, is gradually increasing its influence - globally, but particularly on the European continent - through the use of the Belt and Road Initiative. This has been achieved with the opening of new economic areas of influence along the route of the Initiative. The Initiative will not only promote economic development among China's cooperating countries, but it will also deepen mutual cultural, political, and social cooperation and contacts between China and other countries included in the Initiative. Nevertheless, China still needs the support of the EU and its members to achieve its regional and global goals, as well as to execute its strategic plans. Accordingly, China intends to consolidate its economic, political, and cultural relations both with the EU and the CEECs in line with its goals. It should be noted, however, that the EU's doubts and suspicions regarding the Belt and Road Initiative have not yet been completely eliminated.

\section{References}

China's Belt and Road Initiative in the Global Trade, Investment and Finance Landscape, OECO Business and Finance Outlook 2018, https://www. oecd.org/finance/Chinas-Belt-and-Road-Initiative-in-the-globaltrade-investment-and-finance-landscape.pdf (access 9.04.2020).

Brautigam D., A critical look at Chinese 'debt-trap diplomacy': the rise of a meme, "Area Development and Policy", vol. 5, no. 1/2020.

Central and Eastern Europe: From $16+1$ to $17+1$, https://hkmb.hktdc. com/en/1X0AJYOI/hktdc-research/Central-and-Eastern-EuropeFrom-161-to-171 (access 14.04.2020).

Change in the methodology for anti-dumping investigations concerning China, February, 2016.

Chatzky A., McBride J., China's Massive Belt and Road Initiative, Council on Foreign Relations, https://www.cfr.org/backgrounder/chinas-massivebelt-and-road-initiative (access 15.05.2020).

China's Massive Belt and Road Initiative Fanuary 28, 2020, https://www.cfr.org/ backgrounder/chinas-massive-belt-and-road-initiative (access 7.04.2020). China's new silk route. The long and winding road, PwC's Growth Markets Centre, February 2016, https://www.pwc.com/gx/en/growth-marketscenter/assets/pdf/china-new-silk-route.pdf (access 9.04.2020).

China's Policy Paper on the EU: Deepen the China-EU Comprehensive Strategic Partnership for Mutual Benefit and Win-win Cooperation 2014/04/02, https://www.fmprc.gov.cn/mfa_eng/wjdt_665385/wjzcs/t1143406.shtml (access 10.04.2020). 
Ernst \& Young, ChinesischeUnternehmenskäufe in Europa: Eine Analyse von MEA-Deals 2006-2016, January 2017.

Full text of President Xi's speech at opening of Belt and Road forum, http://www. xinhuanet.com//english/2017-05/14/c_136282982.htm (access 05.04.2020).

Góralczyk J.B., China's interests in Central and Eastern Europe: enter the dragon, "European View", Wilfried Martens Centre for European Studies, 2017, https://www.ce.uw.edu.pl/wp-content/uploads/2017/05/ ev-china.pdf (access 14.05.2020).

Góralczyk J.B., Poland on the Route of the Chinese Silk Road: A Chance for Development or Fust a Challenge?, "Monographies" Faculty of Management University of Warsaw, 2018, http://www.wz.uw.edu.pl/portaleFiles/6133wydawnictwo-/new_structrural_2018/Bogdan_J._Goralczyk.pdf (access 14.05.2020).

Griese O., EU-China relations an assessment by the communications of the European Union, “Asia Europe Journal”, no. 4/2006, DOI: https://doi. org/10.1007/s10308-006-0087-x.

Holslag J., How China's New Silk Road Threatens European Trade, "The International Spectator”, vol. 52, no. 1/2017, DOI: https://doi.org/10.1 080/03932729.2017.1261517.

http://chinaplus.cri.cn/ (access 14.05.2020).

http://www.china-ceec.org/eng/ (access 12.04.2020).

http://www.china-ceec.org/eng/msc_1/dsj/t1410557.htm (access 11.04.2020).

http://www.ecfr.eu/publications/summary/chinas_market_economy_ status_and_the_european_interest_7050 (access 5.04.2020).

http://www.xinhuanet.com/english/2018-07/08/c_137309738.htm (access 12.04.2020).

https://bbr.bg/en/n/bdb-is-actively-involved-in-the-summit-of-heads-ofgovernment-of-china-and-ceebbr.bg/en/n/bdb-is-actively-involved-inthe-summit-of-heads-of-government-of-china (access 12.04.2020).

https://ceec-china-sme.org/hbor-hosts-the-meeting-of-the-china-ceecinterbank-association/ (access 12.04.2020).

https://jb-partners.de/wp-content/uploads/2017/10/EY-ma-chinesischeinvestoren-januar-2017.pdf (access 12.04.2020).

https://trade.ec.europa.eu/doclib/docs/2016/february/tradoc_154241.pdf (access 12.04.2020).

https://www.aiib.org/en/index.html (access 7.04.2020).

https://www.aiib.org/en/projects/list/index.html?status=Approved (access 2.04.2020).

https://www.cceecexpo.org/site_en/ (access 12.04.2020).

https://www.ceec-china-croatia.org/en/about-cooperation/(access 12.04.2020). 
https://www.ecfr.eu/page/-/China_Analysis_Sixteen_Plus_One.pdf(access 12.04.2020).

https://www.epi.org/publication/eu-jobs-at-risk/ (access 12.04.2020).

https://www.fmprc.gov.cn/mfa_eng/wjdt_665385/2649_665393/t1655224. shtml (access 12.04.2020).

Investment, Countries and Regions, China, https://ec.europa.eu/trade/policy/ countries-and-regions/countries/china/ (access 10.04.2020).

Kizeková A., China's Belt and Road Initiative and the $16+1$ Platform: The Case of the Czech Republic, in: Securing the Belt and Road Initiative Risk Assessment, Private Security and Special Insurances Along the New Wave of Chinese Outbound Investments, eds. A. Arduino, X. Gong, Singapore 2018.

Krastev I., Mark L., New World Order: The Balance of Soft Power and the Rise of Herbivorous Powers, European Council on Foreign Relations, October 2007.

Kratz A. et al., Chinese FDI in Europe: 2019 UPDATE Special Topic: Research Collaborations, Mercator Institute for China Studies (MERICS), April 2020, https://www.merics.org/sites/default/files/2020-04/MERICSRhodium\%20Group_COFDI-Update-2020\%20\%282\%29.pdf (access 11.04.2020).

Oziewicz E., Bednarz J., Challenges and opportunities of the Maritime Silk Road initiative for EU countries, "Scientific Journals of the Maritime University of Szczecin”, no. 59(131)/2019.

President Xi Finping Delivers Important Speech and Proposes to Build a Silk Road Economic Belt with Central Asian Countries 2013/09/07, https://www. fmprc.gov.cn/mfa_eng/topics_665678/xjpfwzysiesgjtfhshzzfh_665686/ t1076334.shtml (access 5.04.2020).

Roberts J., George A., The Complete History of China, Sutton Publishing, Basingstoke 2003.

Scott E.R., Xiao J., Unilateral grant of market economy status to China would put millions of EU jobs at risk, "Economic Policy Institute", September, 2015.

Song L., Zhao Q., A Model for the Belt and Road Initiative: China's Cultural Diplomacy Toward Central and Eastern European Countries, in: The Belt and Road Initiative in The Global Arena: Chinese and European Perspectives, eds. Y. Cheng, L. Song, L. Huang, Singapore 2018, DOI: https://doi.org/10.1007/978-981-10-5921-6_4

Sri Lanka's 'new Dubai': will Chinese-built city suck the life out of Colombo?, 2 August 2018, https://www.theguardian.com/cities/2018/aug/02/srilanka-new-dubai-chinese-city-colombo (access 7.04.2020).

Stanzel A., China Analysis: China's Investment In Influence: The Future Of $16+1$ Cooperation, "The European Council on Foreign Relations", no. 199/2016. 
Szunomár Á., One Belt, One Road: Connecting China with Central and Eastern Europe?, in: The Belt and Road Initiative in The Global Arena: Chinese and European Perspectives, eds. Y. Cheng, L. Song, L. Huang, Singapore 2018, DOI: https://doi.org/10.1007/978-981-10-5921-6_5.

The Belt and Road Initiative Progress, Contributions and Prospects, http:// www.china-un.ch/eng/zywjyjh/t1675564.htm (access 4.04.2020).

The Dubrovnik Guidelines for Cooperation between China and Central and Eastern European Countries, 2019.04.17.

Thilo H., Huotari M., Record Flows and Growing Imbalances: Chinese Investment in Europe in 2016, The Mercator Institute for China Studies and The Rhodium Group, January, 2017, http://rhg.com/wpcontent/uploads/2017/01/RHG_Merics_COFDI_EU_2016.pdf (access 10.04.2020).

Trade in Goods with China, European Commission, http://trade.ec.europa. eu/doclib/docs/2006/september/tradoc_113366.pdf (access 10.04.2020).

ZhangR.,ShihuiY.,The Challengeto Maritime Silk RoadandPort Connectivity, The 21st Century Maritime Silk Road Challenges and Opportunities for Asia and Europe, eds. Z. Keyuan, W. Shicun, Y. Qiang, Routledge, London 2019, DOI: https://doi.org/10.4324/9780429058585-4.

Zuokui L., Europe and the "Belt and Road" Initiative: Responses and Risks, Cooperation and Development Institute, http://cdinstitute.eu/web/wpcontent/uploads/2017/08/Liu\%20Zuokui\%20-\%20Europe\%20and\%20 the\%20Belt\%20and\%20Road\%20Initiative.pdf (access 14.05.2020). 